Volume and Issues Obtainable at Center for Sustainability Research and Consultancy

Journal of Business and Social Review in Emerging Economies

ISSN: 2519-089X (E): 2519-0326

Volume 4: Issue 1June 2018

Journal homepage: www.publishing.globalcsrc.org/jbsee

\title{
Development Model Management Education Soft Skill Nurses Hospital Education
}

\author{
${ }^{1}$ Mardliyah, ${ }^{2}$ Rasdi Ekosiswoyo, ${ }^{3}$ Sugiyo, ${ }^{4}$ Titi Prihatin \\ ${ }^{1}$ Kampus Kelud, PPs. Universitas Negeri Semarang, Semarang, Indonesia, mardliyah64@gmail.com \\ ${ }^{2}$ Kampus Kelud, PPs. Universitas Negeri Semarang, Semarang, Indonesia \\ ${ }^{3}$ Kampus Kelud, PPs. Universitas Negeri Semarang, Semarang, Indonesia \\ ${ }^{4}$ Kampus Kelud, PPs. Universitas Negeri Semarang, Semarang, Indonesia
}

\begin{tabular}{l}
\hline ARTICLE DETAILS \\
\hline History \\
Revised format: May 2018 \\
Available Online: June 2018 \\
\hline Keywords \\
Organizational Change, New \\
Public Universities
\end{tabular}

JEL Classification:

D23, D29,J88, J89

\begin{abstract}
This research intent for management model development education soft skill nurse at education hospital, and has influence increase nurse's soft skill on nurses unit. This model development utilize method with approaching Research \& Development from Borg \& Gall (2007). Since time and cost limitation therefore is utilized a portion step of 10 Borg's steps and Gall, which is: (1 ) research \& information as introduction step foreword, (2 ) planing \& develop preliminary form of product as step of makings designs start model, (3) preliminary field testing \& revision as step of early model checking, (4 ) main field testing \& revision as step of product feasibility test-driving and product revision, (5) analize and studies to establish final products (final product), and (6) disemination. Managements model development education soft skill nurse at indispensable Education Hospital whereas nurse candidate or nurse college's students that of its upstream of nurse service, and nurse candidate constitutes one of primal component in education management process in meets the need development soft skill nurse, therefore management model development education soft skill indispensable nurse, so is expected that can also minimalize complain of customer.
\end{abstract}

(C) 2018 The authors, under a Creative Commons Attribution-

NonCommercial 4.0

Corresponding author's email address: mardliyah64@gmail.com

Recommended citation: Mardliyah, Ekosiswoyo, R.Sugiyo,Prihatin, T. (2018). Development Model Management Education Soft Skill Nurses Hospital Education. Journal of Business and Social Review in Emerging Economies, 4(1) $73-80$

DOI: $10.26710 /$ jbsee.v4i1.369

\section{Introduction}

Background

The Means of the quality of nursing service is the professional attitude of nurses in providing nursing services with results that indicate the level of perfection of the nursing service, thus causing a sense of satisfaction in each patient who received it. The more perfect the satisfaction, the better the quality of nursing services provided. Satisfaction is an impact on quality nursing service which is the result of interaction between nurse as giver and patient as recipient of nursing service. In order to realize these expectations, good management is required. Achievement of quality aspects of nursing service to be able to meet patient satisfaction so as to contribute also to job satisfaction. Nurses are expected to have the competence as a professional nurse, whether in the form of hard skill or soft skill. 
The Human Resource Assessment (HRD) review of the last decade conducted by an Emotional Quality Inventory (EQI) institution states that professionals from all over the world who are sampled indicate that IQ only contributes a maximum of $20 \%$ even an average of only $6 \%$ for one's success, compared to EQ. Even the Carrugie Institute of Technology found another proof, that of 10,000 successful people $15 \%$ of their success is determined by technical skills, while $85 \%$ is dominated by personality or soft skills. Edward Wiggam found 400 people or $10 \%$ of the 4000 people who lost their jobs were due to technical inadequacies, meaning $90 \%$ were unemployed because they had personality problems (Christian: 2008). In reality in the nursing service unit of management management of soft skill nurse has not been implemented as a reference to transfer knowledge about soft skill nurse to nurse who already work and student (apprenticeship). This can be seen from the observations made by researchers to some of the Education Hospital in Semarang, and indeed there is no such as in Permendiknas. 65 of 2013 and No. 44 Year 2011.Ronald I-Himler (New York, 2010) says: (1) graduates, faculty, and HR managers assess basic job skills essential for performance; (2) basic work skills need to be provided at college (graduate), entering into curriculum (3) The need for additional training in basic work skills is not required (attitude of graduates), negatively affects the career (faculty attitude), and only gives little effect on the potential for progress career (HR manager attitude), (4) Leadership skills are the most important among the eight dimensions and adjust the model, as the strongest predictors. Soft skill competencies developed are self-management, communication, professional, ethics, teamwork and entrepreneurial skills. The development of soft skill has not been implemented maximally, as for the factors involved in developing soft skill from internal and external education. The inhibiting factor of the development is lack of understanding of soft skill concept by leader, teacher, praktikan, and planning and process. Development of an effective model of implementing management functions, can affect the high success rate of application of the model (Utaminingsih, 2011)

Soft skill is an important component, which should be integrated into the education management model, among which there are 11 most important soft skills, general communication and general ethics. Next: time management, written communication, teamwork, business etiquette, diversity, customer service, problem solving, oral communication, clan leadership (Geana W. Mitchel, 2010). Due to the skills of soft skill that have not been mastered, graduates assess the education that followed has not provided the provision of oral communication skills (along with the author is the important factor) needed in the work environment, together with the experience in teamwork in college is so important for skills in team work, degan internship and work experience provide benefits as a stock of work (Jane Andrew and Helen IIigson, 2008). The existence of soft skill and hard skill are interrelated, Soft skill is an important thing in communicating, followed by problem solving, leadership, teamwork, IT skills, learning to learn skill, Soft skill support work performance and long development time, and so on, Soft skills are not described in curriculum documents, and soft skill development methods include: experience, role playing, demonstrations, teamwork, case studies and problem solving (Kumar Wats, 2009).

Overall,the doctor and nurse in outpatient, hospitalization and emergency room soft skill is good. This can be seen from the average value of the overall soft skill either by themself, fellow nurses, doctor colleagues, and superiors. Similar to soft skills in doctors, soft skills that have high value on nurses are soft skills. But unlike the soft skills of doctors who have bad soft skills, soft nurse skills are not in the poor category ( Made Padma Puspita, 2013). And it can not be denied that nurse leadership has a positive relationship to nurse burnout (Uti Kanste, 2002). Soft skill A person's ability to be sociable and communicate well to the environment in which he is, and is invisible (Tri Hartiti). If you look at the scale of the percentage of nurses' ability in patient care at only $21 \%, 19 \%$ accountability, $18 \%$ patient service management, $17 \%$ patient relationship, $16 \%$ patient communication, $16 \%$ adaptation skills, $14 \%$ patient problem $13 \%$. This situation indicates the low ability of nurses from various aspects of services provided to patients (Oestman \& Bidle, 2012).

Education with the use of technology should be prepared in a professional manner that includes hard 
skills and soft skills, especially on the aspects of communication. Improved soft skills required an active learning environment and evaluation of training program acceptance (Ima, 2010) (Zhang A, 2012). Persuasive leadership has a high impact on interpersonal skills, and has an impact on things such as power and influence, active interaction and attracting others, body language and firmness, able to build relationships, improve communication skills for delegation skills, communication skills for coaching, coaching, coaching, coaching style, bringing talent and global passion in the forefront of business, technology and innovation (William James Us Philosopher, 2013). There is a significant relationship between communication skills score between students who get intervention and who are not getting intervention. Cooperative learning is more efficient in fixing problems and learning is highly recommended for nurses praktikan (Baghcheghi, N, Koohestani, HR Rezaei, K, 2010) .

\section{Methods}

Research and development (R \& D) approach (Rahman, 2011) contains three main components: (1) development model, (2) research and development procedure and (3) product trial.

The characteristics of the R \& D approach are: (1) a preliminary or preliminary study, (2) developing the product, (3) field testing, and (4) product revision. Preliminary studies are intended to find out the facts and to obtain findings related to the products to be developed. Developing a product is a step based on the findings in the preliminary study. The field test is intended to apply the model developed in real situations, while the product revision is a revision of the weakness that will eventually become the final product (Borg and Gall, 2007)

In the preliminary study there are 5 stages as follows:

(1) First stage is the activity of preliminary study, data collecting technique done by observation and interview on research subject. Data collected, reduced, presented and analyzed using relevant theories The sixth stage summary in the research procedure with the R \& D approach is presented in the following table.

(2) The activity of the second stage is the stage of product development by developing the factual model from the first stage.

(3) The third stage is to validate (internal and external) on the Second Stage Conceptual Model.

(4) The fourth stage is to conduct analysis and discussion which eventually becomes the Final Model (final).

Data source used in this research is primary data. The data were obtained from preliminary research activities, FGD, External Validation (extended scope) with data source of research subjects Clinical Instructure, nurses, and praktikan on research objects selected purposively as a result of model feasibility test. Preparation of questionnaires / questionnaires using Guttman Scale (Guttman, 2007). The analysis used is a scalogram to obtain reproducibility coefficient $(\mathrm{Kr})$, and scalability coefficient (Ks), where if the values of $\mathrm{Kr}=>0.90$ and $\mathrm{Ks}=>0.60$ scale are considered good.

The research subjects for the development of conceptual models into hypothetical models are peers, experts, and individual practitioners selected purposively and relevant to the research topic as well as expertise. Internal validation is done through discussion with the result of: (1) correction and input, (2) revision of conceptual model into Hypotetic Model.

Research subjects on model feasibility studies or external validation (extended scope) are Clinical Instructure, nurses and praktikan on selected objects purposively. External validation is done through discussions that result in: (1) corrections and discussions that eventually produce the Final Model.

Data collecting technique in this research is (1) observation, and (2) interview. Both data collecting techniques are equipped with data collection instruments: (1) observation guidelines, and (2) interview guidelines. Internal validation with FGD activity and expert discussion (individual) using data collecting techniques in the form of material discussion notes in structured discussions.

Data analysis technique in preliminary research used interactive analysis technique. Data analysis 
techniques in model pengembanangan and internal validation using qualitative analysis techniques.

\section{Results and Discussion}

A. Factual Model, Soft Skill Nurse Management Model Which Currently Implemented in Educational Hospital

Management Education Nursing soft skills conducted by the three research subjects have not been fully implemented optimally, the causes are: (1) The burden of the task is very complex implementers, in addition to implementing a very wide set of nursing services, still have to run four management functions of soft skill nurse education covering planning, organizing, implementing and controlling for education and training can be implemented in the three research objects as actual implementation of education management of nurse soft skill in Education Hospital, (2) Management of nurse soft skill education with task and responsibility very complex implemented by a head training and secretarial and head nursing in all three hospitals (except in Roemani Hospital, assisted only by administrative staff). (3) The synchronization of the tasks of the Head of Training and the Head of the Maintenance Division which due to their different field of work is sometimes difficult to integrate the time and schedule. (4) Time spent, little time for evaluation of implementation and action in nurse soft skill education management in all three places,Dr. Kariadi Semarang Hospital, Sultan Agung Islamic Hospital and Roemani Muhammadiyah Semarang Hospital

\section{Design Education Management Model Soft Skill Nurse in Education Hospital}

The Factual Model was developed using relevant theories and produced a conceptual model. Then the Conceptual Model carried out internal vacuum through FGD peers, expert discussions and practitioners equipped with a closed and open model questionnaire

Based on FGD results, expert discussions, and practitioners revised the conceptual model which later became a hypothetical model. Further external validation (extended test) on the hypothetical model implemented end of September until the end of December 2016. External validation results obtained correction and input so that the model needs to be revised and called the Hypotetic Revision Model. Furthermore, the Revised Hypothetical Model is carried out analysis and discussion which finally produce the final model. To determine the feasibility test object model used purposive determination among Educational Hospital which is used as research place, that is in RSDK, RSISA, RSR in Semarang. The criteria used are: (1) Educational Hospital Type A, B, C (2) Clinical instructure ratio: nurse candidate $=1$ : (30).

3. Conceptual Model as a Result of Factual Model Development

From the facts presented in the future, then to obtain harmony to achieve effectiveness of management education soft skill nurse done things as follows:

a) Outcomes are reviewed periodically

b) Material alignment in nurse soft skills management model with application in Education Hospital to create effective management of soft skill education Based on the description, the Factual Model can be developed into a Conceptual Model

\section{Internal Validation}

FGD colleagues discussed the model that was held on 22 June 2016, pk10.00-12.00 at RSUP DR. Kariadi followed Ka. Training, Ka. Room (Clinical instructure) as many as 36 people. Sources of data in the form of information from research subjects at the research site, including the head of Nursing, Head of Training and Clinical Instructure. Sampling technique was done by purposive sampling and got sample from Dr. Hospital. Kariadi as much 36 people, Sultan Agung Islamic Hospital of 18 people, and Roemani Muhammadiyah Hospital Semarang, Central Java Indonesia, as much of 12 people.

The data collected were primary data in qualitative form, ie descriptive data of $3 \mathrm{M}$ component (man, method, material) with ordinal scale research and quantitative data using Guttman scaled (Guttman, 2007). To assess the undimensionality of a variable on this scale, a scalogram analysis is performed. 


\section{Internal Validation Results}

FGD results of peers in the form of inputs for refinement of models and manuals, Expert and nurse candidate validation results provide input for presentation report dissertation, model, manual management education manual soft skills Model. Data processing is analyzed by quantitative approach. The magnitude of the difference in the improvement of indicators in the development model between before and after the activity process is done by Guttman Scale (Guttman 2007).

The research instrument used interview, questionnaire and observation. Interviews are used to obtain information about Clinical Instructure's needs for model development. Questionnaires are used to obtain data input about the model execution activity. Observation is used to observe and observe the activities of clinical instructors in before and after the implementation of model development.

Preparation of questionnaires as research instruments is a technique used to collect primary data from the respondents. Preparation of questionnaires / questionnaires using Guttman Scale (Guttman, 2007)

6. Hypothetics as a Result of Conceptual Model Development

Conceptual models are modeled through FGD peers, expert discussions and individual practitioners. Discussion results obtained from input and observe the following provisions: (1) model design, (2) model design background, (3) model design purposes, (4) model design scope, and (5) model structure.

Summarizing the results of the FGD and internal validation, then made a direct improvement on report writing.

7. External Validation For Model Feasibility Test

Hypothetical model, integration of three types of education management model of nurse soft skill, soft skill component distribution, details of the relationship between the four functions of soft skill education management with the aspects of soft skill education management in the process sub-system of the education system, the implementation of soft feasible to be used, then the model is revised. The result of the model revision becomes the Revised Hypothetical Model.

Preparation of questionnaires / questionnaires using the Gufman scale. The Gufman scale is to measure the attitudes, opinions, and perceptions of a person or group of social phenomena (Sulastri, 2007). Each instrument item using the Gufman Scale has both positive and negative gradations.

8. Final Model of Education Management Soft Skill Nurse in Education Hospital

The Revised Hypothetical Model to be a Final Model takes into account input and refinement with due regard to the need for the development of nurse soft skills management education as a culture in the Education Hospital and the needs of change management. The entries are as follows:

1) Improving Education Management Guidebook Soft skill Nurse by:

a. Clarify: (1) role of cadic and care field in direct action and coordination, (2) implementation of mapping of education management development of nurse soft skill implemented by chlinical instructure (3) nurse practitioners and nurses in their capacity to support the implementation of education management soft skill nurse Teaching hospital

b. Adding management changes in the implementation of management education soft skill nurses at the Education Hospital

2) Affirmation of obligation to follow the activity of management development of nurse soft skill education as culture of hospitalImprove the guidance book and education management guidance of soft skill nurse become part which is scheduled as activity of education hospital training activity. The Final Model shows that the management model of the nurse soft skill education ranging from the background of needs and demands, then in determining the vision, mission and objectives, and for execution on the basis of implementation or the term often used is guidance. By unraveling the management functions that start from how planning development, implementation and control. Consists of a composition of 9 essential elements of the management model of education Soft skill nurse. Which further outlines 11 soft skill materials that are agreed upon and applicable. Then how the development of soft skills into needs and culture that mixed by using the theory approach Krathwall and Kihajar Dewantoro which is then evaluated using a conscientious approach, Soft skillperawat education management model is a model of nursing education management by promoting the activeness of nurse candidate in the education process at Educational Hospital Clinical instructure no 
longer serves as a speaker of a nursing material, but as a facilitator by providing guidance, stimulus and guidance through instruction manual of learning guide that has been prepared so that the practitioners not only get the material during the implementation of education, but gain experience the real from a series of activities.

The concept of education management model of nurse soft skill consists of 9 essential elements

a) Clinical Instructure

b) Nurse candidate (Student)

c) Concept of Learning Guide

d) In Class Learning Concept

e) Concept of Student Club Development

f) The concept of Hospital Visit

g) The Incubassion Process Concept

h) Product Development Concept

i) Soft skill Ring

Of the nine essentials are translated into 11 soft skill materials which include affection, hospitality, empathy, comunicaion skill, leadership, team work, confident, ethical behavior, interphreunership, concience, human relations inside. The eleven soft skill materials became a culture by using the Krathwall theory approach, covering a series of characteristics, actualization, organizing, internalizing, respecting, responding and receiving combined with Ki Hajar Dewantoro's approach of feeland understanding . Furthermore the eleven soft skill materials are evaluated with a conscientious approach. The proof is the presence of students, attendance list of teachers, deliberations, and results reports.

\section{Conclusion}

The development of education management model of nurse soft skill at the Education Hospital needs to be done because it found that in all three objects have not implemented the management of softskill nurse education in Education Hospital with programmed, planned and measured, not yet used approach of four management functions; planning, organizing, implementing and controlling.

In the three objects of research has not put the development activity of management education soft skill nurses at the Hospital of Education as an activity unit of training and nursing at the Education Hospital, but found in Dr. Hospital. Kariadi Semarang is going to make a model management education soft skill nurse because feel is needed.

Increasing the quality of sustainable care services as the most important part in the accreditation of the Hospital, the development of educational management model of nurse soft skill in the Hospital of Education is very necessary while the nurse candidate or the nursing students is the upstream of nursing service and nurse candidate is one of the most important components in the education management process in meet the development needs of nurse soft skill hence the development of management model of soft skill of nurse education is needed in three research object, so it is expected also able to minimize complain from customer.

Dr.Karyadi Hospital Semarang felt helped by the Soft Skill Education Management Model in Education Hospital.

\section{Suggestion}

Development of education management model of nurse skill soft skill can be utilized for education and training organizers in Education Hospital, Model can be adopted and applied in the implementation of management of nurse soft skill training on nurse candidate This management model of nurse soft skill training is also expected to deliver beginner and nurse candidate to success, being an independent, efficient and effective person. 
Implementation of models to obtain optimal results and quality. So it is necessary: (1) discipline over time, and (2) objectivity in high commitment in the activity of management development of soft skill training nurse candidate, both inside and outside the Hospital.

For the decision-making institution of the scope of education and training providers in the Education Hospital, the model can be used as a reference in formulating policies related to the development of nurse soft skill education management.

\section{Daftar Pustaka}

Andrew,S., dan Helen H. 2008. Graduate Employability, Soft skill Versus Hard Business Knowledge: A European Study. Higher Education in Europe,Vol. 33, N0. 4, December 2008.

Borg, W.R., clan Gall, M.D. 1989. Educutational Research: Anlntroduction, Fifth Edition 1. New York: Longman.

Heimler, R. 2010. “Attitude of College Graduates, Fakulty, and Human Resource Managers Regarding The Importance of Skill Aqquired in College andNeeded for Job Performance and Career Advancement Potential in TheRetail Sector". Laporan Penelitian. New York: Dowling College, Oakdale.

Havard University. Antara Hard Skill dan Softskill. Artikel. Terjemahan. http://www.infocomcareer.com. (Diunduh 18-08-2012).

Krathwoll. 2014. http://scholar.google.co.id/ Methods of Educational and Social

Kemenristekdikti. 2000. SK No. 232/U/2000; .Pedoman Penyusunan Kurikulum Pendidikan Tinggi Dan Penilaian Hasil Belajar Mahapraktikan. Jakarta

Michell G.W., Leane B.S.,dan Bonnie J.W. 2010. "Essential Softskills For Succes in The Twenty - First Century Workforce as Perceived by Business

Rachman, M. 2011. Metode Penelitian Pendidikn Moral Dalam Pendekatan, Kuantitatif, Kualitatif, Campuran, Tindakan dan dan Pengembangan. Semarang : Unnes Press.

Rohman, N.U. 2012. Pengangguran Terdidik Mernprihatinkan. SuaraMerdeka.com. 21 Januari 2012. (Diunduh 20 Agustus 2012).

Utaminingsih, S. 2011. "Model Manajemen Pengembangan Softskill Sekolah Menengah Bidang Keahlian Pariwisata di Kota Semarang”. Disertasi.Semarang: Universitas Negeri Semarang

Wats, R.K. 2009. "Developing Soft Skill in Student." Laporan Penelitian, The International Journal of Learning. Vo1. 15, No. 12.

Wiles, J, and Joseph B. 2007. Curriculum Developmen- a Guide to Practice. New Jersey: Pearson Education, Inc.

Wikipedia, 2014. http://id.m.wikipedia.org/ Ki Hajar Dewantara 